\title{
KEADILAN RESTORATIF SEBAGAI ALTERNATIF DALAM PENYELESAIAN TINDAK PIDANA DAN PENGARUHNYA DALAM SISTEM PERADILAN PIDANA DI INDONESIA
}

\author{
Henny Saida Flora \\ Fakultas Hukum Universitas Katolik St. Thomas Medan Sumatera Utara \\ Email: hennysaida@yahoo.com
}

\begin{abstract}
The criminal punishment system in the Criminal Code basically still retains the retributive paradigm, namely providing appropriate retaliation for crimes committed by perpetrators and still focusing on prosecuting criminals, not paying attention to the recovery of losses. and the suffering of the victims lost due to crime. Retributive paradigm with the aim of providing a deterrent effect for the perpetrator not to repeat the crime again and prevent the community from committing a crime. The use of the retributive paradigm has not been able to recover the losses and sufferings experienced by victims. Even though the offender was convicted and sentenced, the victim's condition could not return to normal. With this weakness, the idea of a punishment system emerged that was oriented towards the recovery of victims and suffering of victims, which was called restorative justice, because the victims were the parties most harmed by crime. By using the normative juridical method it can be concluded that the settlement of crimes with restorative justice can accommodate the interests of the parties, including victims because the victims are involved in determining sanctions for the perpetrators. Restorative justice returns conflict to the most affected parties - victims, perpetrators, and the community, and prioritizes their interests. With law enforcement through restorative justice it is expected that the losses and suffering suffered by victims and their families can be restored and the burden of guilt of criminals can be reduced because they have received forgiveness from victims or their families.
\end{abstract}

Keywords: Restorative Justice, Criminal Settlement, Criminal Justice System

\begin{abstract}
ABSTRAK
Sistem hukuman pidana dalam KUHP pada dasarnya masih mempertahankan paradigma retributif, yaitu memberikan pembalasan yang sesuai untuk kejahatan yang dilakukan oleh pelaku dan masih fokus pada penuntutan pelaku kejahatan, belum memperhatikan pemulihan kerugian. dan penderitaan para korban hilang karena kejahatan. Paradigma retributif dengan tujuan untuk memberikan efek jera bagi pelaku untuk tidak mengulangi kejahatan lagi dan mencegah masyarakat melakukan kejahatan. Penggunaan paradigma retributif belum mampu memulihkan kerugian dan penderitaan yang dialami korban. Meskipun pelaku telah dinyatakan bersalah dan dijatuhi hukuman, kondisi korban tidak bisa kembali normal. Dengan kelemahan ini, muncul gagasan tentang sistem hukuman yang berorientasi pada pemulihan korban dan penderitaan korban, yang disebut keadilan restoratif, karena korban adalah pihak yang paling dirugikan karena kejahatan. Dengan menggunakan metode yuridis normatif dapat disimpulkan bahwa penyelesaian kejahatan dengan peradilan restoratif dapat mengakomodasi kepentingan para pihak, termasuk korban karena korban terlibat dalam penentuan sanksi bagi pelaku. Keadilan restoratif
\end{abstract}


mengembalikan konflik ke pihak yang paling terkena dampak - korban, pelaku, dan masyarakat, dan mengutamakan kepentingan mereka. Dengan penegakan hukum melalui peradilan restoratif diharapkan bahwa kerugian dan penderitaan yang dialami oleh korban dan keluarga mereka dapat dipulihkan dan beban rasa bersalah para penjahat dapat dikurangi karena mereka telah menerima pengampunan dari korban atau keluarganya.

Kata Kunci: Keadilan Restoratif, Penyelesaian Tindak Pidana, Sistem Peradilan Pidana

\section{Pendahuluan}

Keadilan restoratif merupakan suatu bentuk model pendekatan baru dalam penyelesaian perkara pidana. model pendekatan restorative justice ini sebenarnya telah digunakan di beberapa negara dengan fokus pendekatannya kepada pelaku, korban dan masyarakat dalam proses penyelesaian kasus hukum yang terjadi diantara mereka. Walaupun model pendekatan ini masih banyak diperdebatkan dalam tataran teori oleh para ahli, namun dalam kenyataannya tetap tumbuh dan eksis serta mempengaruhi kebijakan dan praktek hukum di banyak negara. Permasalahan yang terjadi dalam masyarakat Indonesia merupakan suatu fenomena sosial yang senantiasa ada sejak mulainya kehidupan manusia karena manusia merupakan makhluk sosial yang mempunyai kehendak atau kepentingan yang tidak seragam antara manusia yang satu dengan manusia yang lain. semakin tingginya kompleksitas dan persaingan yang semakin keras dalam kehidupan bermasyarakat cenderung meningkatkan atau setidaknya berpotensi menimbulkan berbagai permasalahan. Muncul banyaknya perkara atau sengketa dalam masyarakat bila tidak ditangani dengan baik sudah tentu akan mengganggu keseimbangan dalam masyarakat terlebih apabila masalah-masalah tersebut berkaitan dengan suatu tindak pidana.

Secara umum penyelesaian masalah atau sengketa ini dapat ditempuh dengan dua jalur yaitu dengan menggunakan jalur litigasi dan jalur non litigasi. Pada dasarnya kedua jalur ini bertujuan untuk menciptakan suatu keadilan bagi masyarakat pada umumnya, dan keadilan untuk para pihak pada khususnya. Penggunaan salah satu jalur penyelesaian perkara litigasi maupun non litigasi tersebut akan sangat ditentukan oleh konsep dan tujuan penyelesaian perkara yang ingin dicapai oleh para pihak serta yang tidak kalah pentingnya adalah itikad baik dari para pihak untuk menyelesaiikan perkara tersebut.

Dewasa ini apabila terjadi suatu tindak pidana, masyarakat cenderung menggunakan jalur pengadilan yang secara konsep akan menciptakan keadilan namun dalam kenyataannya hal ini merupakan hal yang tidak mudah untuk dicapai. Hal ini dikarenakan hasil yang akan dicapai dari proses penyelesaian perkara dengan jalur peradilan besifat win lose solution, dimana 
akan terdapat pihak yang menang dan ada pihak yang kalah. Dengan kenyataan seperti ini penyelesaian suatu perkara melalui jalur peradilan tradisional apda umumnya kerap menimbulkan satu rasa tidak enak di benak pihak yang kalah, sehingga berupaya untuk mencari keadilan ke tingkat peradialn lebih lanjut.

Terkait dengan hal itu, Satjipto Rahardjo menyatakan, bahwa penyelesaian perkara melalui sistem peradilan yang berujung pada vonis pengadilan merupakan suatu penegakan hukum ke arah jalur lambat. Hal ini karena penegakan hukum itu melalui jarak tempuh yang panjang, melalui berbagai tingkatan mulai dari kepolisian, kejaksaan, pengadilan negeri, pengadilan tinggi bahkan sampai ke Mahkamah Agung. Pada akhirnya berdampak pada penumpukan perkara yang jumlahnya tidak sedikit di pengadilan.

Disamping menimbulkan penumpukan perkara dalam banyak kasus yang terjadi khususnya yang terjadi di Indonesia, misalnya kasus pencurian sandal jepit yang menimpa AAL, kasus pencurian piring yang menimpa Rasminah, kasus pencurian kakao yang senilai Rp. 2.500.000 yang menimpa Aminan, dan kasus pencurian buah randu, kasus pencurian semangka serta beberapa kasus lainnya yang sejenis tidak seharunya dituntut dan masuk ke pengadilan. Dikatakan demikian karena putusan hakim dalam kasuskasus tersebut dan kasus-kasus lain sejenis banyak dikecam publik karena dinilai tidak memenuhi rasa keadilan. Publik menilai bahwa aparat penegak hukum yang dalam hal ini adalah polisi dan jaksa seharusnya tidak melanjutkan perkara tersebut ke pengadilan karena dapat diselesaikan melalui pola-pola penyelesaian yang disepakati oleh keduabelah pihak. Hal ini menjadi menarik untuk diperbincangkan mengingat bahwa sifat dari hukum pidana adalah ultimum remidium yang berarti suatu upaya terakhir yang ditempuh bilamana tidak ada upaya lain untuk menyelesaikan perkara. Namun pada perkembangannya hukum pidana justru digunakan seagai upaya pertama dalam menyelesaikan suatu masalah justru digunakan sebagai upaya pertama dalam menyelesaikan suatu masalah antara orang yang satu dengan yang lain. pergeseran fungsi hukum pidana ini menunjukkan bahwa masyarakat telah meninggalkan sedikit demi sedikit budaya berhukum.

Dengan demikian dapat dilihat bahwa fenomena yang terjadi menunjukkan dalam hukum Indonesia masih sering didapati fakta bahwa keadilan yang diharapkan melalui jalur formal ternyata belum tentu mencerminkan rasa keadilan, mahal, berkepanjangan, melelahkan dan tidak menyelesaikan masalah serta lebih parah lagi adalah di dalamnya penuh dengan praktek korupsi, kolusi dan nepotisme. Dari hal-hal tersebut ternyata banyak kasus yang terjadi dalam masyarakat pada dasarnya tidak layak 
diteruskan ke pengadilan atau bahkan menjalani pemidanaan.

Ketidakpuasan terhadap mekanisme pemidanaan yang ada saat ini (salah satunya karena dirasakan tidak memenuhi rasa keadilan dan tujuan yang ingin dicapai dari pemidanaan itu sendiri yaitu untuk mencegah dan menanggulangi tindak pidana). telah memicu sejulah pemikiran untuk melakukan berbagai upaya alternatif dalam menjawab persoalan-persoalan yang berkaitan dengan penanganan tindak pidana yang terjadi. Sistem peradilan pidana dapat dipahami sebagai suatu usaha untuk memahami serta menjawab pertanyaan apa tugas hukum pidana dalam masyarakat dan bukan sekedar bagaimana hukum pidana di dalam undangundang dan bagaimana hakimn menerapkannya.

Berdasarkan hal tersebut, dalam penegakan hukum di Indonesia dewasa ini sudah seyogianya para aparatur penegak hukum khususnya polisi, jaksa dan hakim serta aparatur penegak hukum lain lebih mengedepankan prinsip keadialn restoratif. Munculnya konsep keadilan restoratif dikarenakan atas ketidakpuasan dan rasa frustrasi di banyak dunia terhadap hukum pidana formal dan pemidanaan yang nyatanya sering kali tidak dapat menjawab persoalan-persoalan dalam sistem peradilan pidana yang dianggap tidak lagi dapat memberikan keadilan, perlindungan terhadap hak asasi manusia, tiadanya transparansi dalam penanganan perkara pidana serta kepentingan umum yang seringkali diabaikan atau semakin tidak dirasakan.

Konsep keadilan restoratif adalah alternatif yang populer di berbagai belahan dunia untuk penanganan perbuatan melawan hukum karena menawarkan solusi yang komprehensif dan efektif. Keadilan restoratif bertujuan untuk memberdayakan para korban, pelaku, keluarga dan masyarakat untuk memperbaiki suatu perbuatan melawan hukum dengan menggunakan kesadaran dan keinsyafan sebagai landasan untuk memperbaiki kehidupan bermasyarakat.

Konsep keadilan restoratif sebenarnya telah lama dipraktikan masyarakat adat Indonesia, seperti di Papua, Bali, Toraja, Minangkabau, dan Komunitas tradisional lain yang masih kuat memegang kebudayaan. Apabila terjadi suatu tindak pidana oleh seseorang maka penyelesaian sengketa diselesaikan di komunitas adat secara internal dengan perdamaian tanpa melibatkan aparat negara. Walaupun perbuatan pidana umum yang ditangani masyarakat sendiri bertentangan dengan hukum positif, terbukti mekanisme ini telah berhasil menjaga harmoni di tengah masyarakat.

Mekanisme penyelesaian perkara berdasarkan keadilan restoratif didasarkan pada musyawarah mufakat dimana para pihak diminta berkompromi untuk mencapai sebuah kesepakatan. Setiap individu diminta untuk mengalah dan menempatkan 
kepentingan masyarakat di atas kepentingan pribadi demi menjaga keharmonisan bersama. Konsep musyawarah terbukti lebih efektif untuk menyelesaikan sengketa dalam masyarakat di tengah kegagalan peran negara dan pengadilan dalam memberikan rasa keadilan.

Penyelesaian perkara pidana dengan pendekatan atau konsep keadilan restoratif ini lebih menitikberatkan pada adanya partisipasi langsung baik dari pihak pelaku, korban dan masyarakat dalam proses penyelesaian perkara. Di samping itu konsep keadilan restoratif lebih menekankan kepada nilai keseimbangan, keselarasan, harmonisasi, kedamaian, ketentraman, persamaan, persaudaraan, dan kekeluargaan dalam masyarakat daripada penghukuman atau pemenjaraan. Upaya penyelesaian perkara yang dilakukan dengan cara ini tidak hanya menyelesaikan permasalahan yang timbul tetapi lebih dalam dari itu konsep penyelesaian perkara dengan menggunakan pendekatan keadilan restoratif dirasakan lebih memberikan rasa keadilan masyarakat.

Prinsip-prinsip keadilan restoratif secara sederhana dapat diartikan sebagai sebuah model penyelesaian perkara di luar lembaga pengadilan atau atau sering disebut dengan out of court settlement yang lebih memperhatikan keadilan, tujuan dan keinginan para pihak dengan konsep victim awareness work. Dalam kerangka normatif maupun dari kerangka teoretis prinsip penyelesaian perkara pidana di luar lembaga pengadilan atau out of court settlement banyak dipertanyakan namun dalam kenyataannya terdapat juga beberapa praktek penyelesaian perkara pidana di luar sistem peradilan pidana.

Pendekatan keadilan restoratif yang menjunjung tinggi nilai keseimbangan, keselarasan, harmonisasi, kedamaian, ketentraman, persamaan, persaudaraan, dan kekelurgaan tentu selaras dan sesuai dengan nilai-nilai yang terkandung dalam pancasila. Dengan demikian pendekatan keadilan restoratif pada hakikatnya telah sesuai dengna jiwa bangsa Indonesia yang lebih mengedepankan nilai-nilai kekerabatan, paguyuban, kekeluargaan, gotong royong, toleransi, mudah memaafkan, dan mengedepankan sikap ayng mendahulukan kepentingan bersama.

Di samping sesuai dengan nilai-nilai yang terdapat dalam pancasila, pendekatan keadilan restoratif yang menjunjung tinggi nilai keseimbangan, keselarasan, harmonisasi, kedamaian, ketentraman, persamaan, persaudaraan, dan kekeluargaan selaras pula dengan nilai-nilai yang terdapat dalam hukum adat. Dalam hal ini dapat dilihat bahwa penyelesaian perkara di Indonesia termasuk penyelesaian perkara dengan menggunakan hukum adat seringkali dilakukan dengan cara-cara yang melibatkan pelaku, korban, masyarakat serta tokoh 
masyarakat yang dianggap dapat menengahi dan menyelesaikan permasalahan tersebut.

Perdamaian antara korban dan pelaku atau pihak yang bersengketa serta perdamaian yang dimaksud bertujuan agar keadaan yang menimbulkan perselisihan atau persengketaan itu bisa dinetralisir sehingga antara korban dan pelaku kembali menjadi seperti semula sebelum terjadi persengketaan inilah yang dinamakan perdamaian. Di samping itu dengan dilaksanakannya konsep perdamaian dalam menyelesaikan permasalahan tentunya dapat mengatasi segala permasalaan dalam sistem peradilan pidana tradisional misalnya terjadinya penumpukan perkara, permasalahanpermasalahan dalam lembaga pemasyarakatan dan lain sebagainya.

Berdasarkan uraian tersebut di atas maka yang menjadi permasalahan dalam penulisan ini bagaimanakah konsep keadilan restoratif dalam penegakan hukumnya dalam sistem peradilan pidana di Indonesia.

Dalam menyelesaikan suatu perkara pidana baik pola penegakan hukumnya maupun personil aparat penegak hukumnya tidaklah adil apabila menyelesaikan suatu persoalan pidana hanya memperhatikan salah satu kepentingan saja, baik pelaku maupun korban. Maka diperlukan suatu teori pemidanaan yang mewakili semua aspek dalam penyelesaian suatu perkara baik korban, pelaku dan masyarakat oleh karenanya diperlukan adanya kombinasi antara satu teori dan teori lainnya. Untuk itu diperlukan pendekatan multidimensional yang bersifat mendasar terhadap dampak pemidanaan, baik yang menyangkut dampat yang bersifat individual maupun keharusan untuk memilih teori integratif tentang tujuan pemidanaan yang dapat mempengaruhi fungsinya dalam rangka mengatasi kerusakan-kerusakan yang diakibatkan oleh suatu tindak pidana.

Keadilan restoratif merupakan filosofi hukum baru yang merupakan gabungan dari teori pemidanaan yang ada. Keadilan restoratif yang berorientasi pada penyelesaian perkara yang memfokuskan perhatian kepada pelaku, korban maupun masyarakat. Di sini keadilan restoratif mengandung nilai teori pemidanaan yang klasik yang terfokus pada upaya pemulihan korban yang terdapat dalam teori pemidanaan retributif, deterrence, rehabilitation, resocialization. Selain terfokus pada pemulihan pelaku keadilan restoratif juga memperhatikan kepentingan korban dan masyarakat. Adapun ciri-ciri dari pelaksanaan restorative justice dalam merespon suatu tindak pidana adalah sebagai berikut :

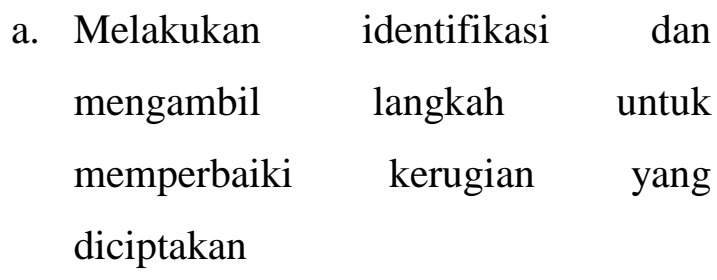

b. Melibatkan seluruh pihak yang terkait 
c. Adanya upaya untuk melakukan masyarakat Indonesia dengan warisan transformasi hubungan yang ada keanekaragaman adat atau budaya (kearifan selama ini antara masyarakat dengan lokal) dan nilai-nilai yang hidup dalam pemerintah dalam merespons tindak pidana.

Dengan demikian inti dari restorative justice adalah penyembuhan, pembelajaran, moral dan partisipasi dan perhatian masyarakat, dialog, rasa memaafkan, tanggung jawab, dan membuat perubahan yang semuanya itu merupakan pedoman bagi proses restorasi dalam perspektif restorative justice. Restorative justice bertujuan untuk memberdayakan para korban, pelaku, keluarga, dan masyarakat untuk memperbaiki suatu perbuatan melawan hukum dengan menggunakan kesadaran dan keinsyafan sebagai landasan untuk memperbaiki kehidupan bermasyarakat. Menurut Wright, konsep keadilan restoratif pada dasarnya sederhana. Ukuran keadilan tidak lagi berdasarkan pembalasan setimpal dari korban kepada pelaku (baik secara fisik, psikis, atau hukuman) namun perbuatan yang menyakitkan itu disembuhkan dengan memberikan dukungan kepada korban dan mensyaratkan pelaku untuk bertanggung jawab dengan bantuan keluarga dan masyarakat bila diperlukan.

\section{Hasil dan Analisis}

Konsepsi keadilan restoratif pada dasarnya bukan suatu hal yang baru atau asing lagi bagi masyarakat Indonesia. Dikatakan demikian karena selama ini atau proses penyelesaian masalah (sengketa) pada hakikatnya sesuai dengan konsep atau nilai-nilai yang terkandung dalam keadilan restoratif.

Menurut Rufinus Hotmaulana Hutauruk, konsep dasar pendekatan restoratif justice berupa tindakan untuk membangan kembali hubungan yang rusak akibat tindak pidana telah lama dikenal dan dipraktikkan di dalam hukum adat yang berlaku di Indonesia. Selain itu filosofi dasar tujuan pendekatan restoratif adalah untuk memulihkan keadaan pada keadaan semula sebelum tejadinya konflik adalah identik dengan filosofi mengembalikan keseimbangan yang terganggu yang terdapat dalam hukum adat Indonesia.

Konsep penanggulangan tindak pidana melalui restorative justice dianggap sebagai salah satu pilihan untuk menutupi kelemahan-kelemahan dan ketidak puasan terhadap pendekatan retributif dan rehabilitatif yang selama ini telah dipergunakan dalam sistem peradilan pidana pada umumnya.

Menurut Gordon Bazemore pokokpokok pemikiran dalam paradigma peradilan yang restoratif meliputi beberapa hal sebagai berikut : 
a. Tujuan penjatuhan sanksi. Terdapat asumsi bahwa di dalam tujuan penjatuhan sanksi maka korban harus diikut sertakan secara aktif untuk terlibat dalam proses peradilan. Indikator pencapaian tujuan penjatuhan sanksi tercapai atau tidak dapat dapat dilihat dengan indikator apakah korban telah direstorasi, adanya kepuasan korban, besarnya ganti rugi, kesadaran pelaku atas perbuatannya, jumlah kesepakatan perbaikan yang dibuat, kualitas pelayanan dan keseluruhan proses yang terjadi. Bentuk-bentuk sanksi yaitu restitusi, mediasi pelaku dan korban, pelayanan korban, restorasi masyarakat, pelayanan langsung pada korban atau denda restoratif. Dalam penjatuhan sanksi ini harus mengikutsertakan pelaku, korban, masyarakat dan para penegak hukum secara aktif. Pelaku akan berperan aktif dalam merestore kerugian korban, dan menghadapi korban wakil korban. Sebaliknya korban aktif dalam semua tahapan proses dan akan membantu dalam penentuan sanksi bagi si pelaku. Masyarakat dalam hal ini terlibat sebagai mediator atau fasilitator (yang dalam hal ini penegak hukum) membantu korban dan mendukung pemenuhan kewajiban pelaku.

b. Rehabilitasi pelaku. Fokus utama peradilan restoratif adalah untuk kepentingan dan membangun secara positif. Dengan demikian pelaku merupakan sumber utama. Untuk kepentingan rehabilitasi pelaku diperlukan perubahan sikap dari lembaga kemasyarakatan dan paradigm pemidanaan dewasa ini. Rehabilitasi pelaku dalam konsep keadilan restoratif dilakukan dengan pelaku yang bersifat konseling dan terapi untuk memotivasi keterlibatan aktif para pihak.

c. Aspek pelindungan masyarakat. Nilai dasar yang yang berikutnya yang ada dalam peradilan restoratif adalah tercapainya perlindungan masyarakat dengan upaya kolaborasi sistem peradilan dan masyarakat umum untuk mengembangkan pencegahan. Penyekapan atau pemenjaraan dibatasi hanya sebagai upaya terakhir. Masyarakat dalam hal ini bertanggung jawab dan berperan aktif dalam mendukung terselenggaranya restorasi. Indikator tercapainya perlindungan masyarakat apabila angka residivis turun, sementara pelaku berada di bawah pengawasan masyarakat, masyarakat merasa aman dan yakin atas peran sistem peradilan restoratif, pelibatan rekan dekat pelaku, keluarga dan lembaga kemasyarakatan untuk mencegah terjadinya kejahatan, ikatan sosial dan reintegrasi dalam konsep ini senantiasa harus ditingkatkan. 
Berdasarkan pendapat tersebut indikator dalam peradilan restoratif dapat dilihat dari peran serta pelaku, korban, masyarakat dan para profesional atau para penegak hukum. masing-masing berperan sebagai berikut :

a. Pelaku : pelaku aktif untuk merestore kerugian korban dan masyarakat, dengan demikian ia harus menghadapi korban/wakil korban serta menghadapi masyarakat.

b. Korban: aktif terlibat dalam semua tahapan atau proses penyelesaian perkara dan berperan aktif dalam mediasi dan ikut menentukan sanksi bagi pelaku

c. Masyarakat: terlibat sebagai mediator, bertugas untuk mengembangkan pelayanan masyarakat dan menyediakan kesempatan, bagi pelaku sebagai wujud kewajiban reparatif, membantu korban dan mendukung pemenuhan kewajiban pelaku

d. Para profesional atau para aparat penegak hukum : memfasilitasi berlangsungnya mediasi, memberikan jaminan terselenggaranya restoratif, mengembangkan opsi-opsi pelayanan masyarakat secara kreatif/restorative serta melibatkan anggota masyarakat dalam proses penyelesaian perkara.

Pendekatan keadilan restoratif dewasa ini telah menjadi model dominan dari sistem peradilan pidana dalam perkembangan sejarah dan peradaban manusia. Penyelesaian perkara dengan pendekatan keadilan restoratif pada umumnya dilakukan dengan menerapkan ganti rugi oleh pelaku dan keluarganya kepada korban dan/atau keluarganya serta kepada masyarakat. Pemulihan yang dilakukan oleh pelaku bisa juga berupa ganti rugi, pekerjaan sosial atau melakukan sesuatu perbaikan atau kegiatan tertentu sesuai dengan keputusan bersama yang telah disepakati semua pihak dalam pertemuan yang dilakukan. Dengan demikian tepatlah kiranya apabila dikatakan bahwa model penyelesaian dengan pendekatan keadilan restoratif merupakan suatu proses di luar peradilan formal yang dijalankan dengan memperhitungkan pengaruh yang lebih luas terhadap korban, pelaku dan masyarakat itu sendiri.

Menurut Komariah E. Sapardjaja, prinsip-prinsip dasar yang terkandung dalam pendekatan keadilan restoratif adalah :

a. Keadilan yang dituntut adalah adanya upaya pemulihan bagi pihak yang dirugikan

b. Siapapun yang terlibat dan terkena dampak tindak pidana harus mendapat kesempatan untuk berpartisipasi penuh dalam menindaklanjutinya.

c. Pemerintah berperan dalam menciptakan ketertiban umum sementara masyarakat membangun dan memelihara perdamaian. 
Dalam konsep restorative justice penanganan kejahatan atau tindak pidana yang terjadi bukan hanya menjadi tanggung jawab negara akan tetapi juga merupakan tanggung jawab masyarakat. Oleh karena itu konsep keadilan restoratif dibangun berdasarkan pengertian bahwa kejahatan atau tindak pidana yang telah menimbulkan kerugian (baik bagi korban ataupun masyarakat luas) harus dipulihkan kembali baik kerugian yang diderita oleh korban maupun kerugian yang diderita oleh masyarakat. Dengan demikian keterkaitan dan keterlibatan anggota masyarakat sangat dibutuhkan untuk membantu memperbaiki kesalahan dan penyimpangan yang terjadi dalam lingkungan masyarakat yang bersangkutan.

Pemberian penghargaan dan penghormatan pada korban dan/atau keluarganya dan masyarakat dengan mewajibkan pelaku dan/atau keluarganya melakukan pemulihan kembali atas akibat dari tindak pidana yang telah dilakukannya dapat berupa ganti rugi, pekerjaan sosial atau melakukan sesuatu perbaikan atau kegiatan tertentu sesuai dengan keputusan bersama yang telah disepakati semua pihak dalam pertemua yang dilakukan.

Menurut Rufinus Hotmaulana Hutauruk bahwa proses penanggulangan tindak pidana melalui pendekatan restoratif adalah suatu proses penyelesaian tindak pidana yang bertujuan untuk memulihkan keadaan yang di dalamnya termasuk ganti rugi terhadap korban melalui cara-cara tertentu yang disepakati oleh para pihak yang terlibat di dalamnya. Prinsip utama penyelesaian tindak pidana melalui pendekatan restoratif merupakan suatu penyelesaian yang bukan hanya sekedar alat untuk mendorong seseorang untuk melakukan kompromi terhadap terciptanya kesepakatan, tetapi pendekatan dimaksud harus mampu menembus ruang hati dan pikiran para pihak yang terlibat dalam proses penyelesaian dalam memahami makna dan tujuan dilakukannha suatu pemulihan dan sanksi yang diterapkan adalah sanksi yang memulihkan dan bersifat mencegah.

Dengan demikian terjadi pergeseran pemikiran dari model penghukuman tradisional (pembalasan dan rehabilitasi) kepada model penghukuman yang memberikan keadilan yakni dengan memberikan akses kepada keadilan itu sendiri terutama keadilan yang ditujukan pada keadilan masyarakat secara luas. Hal ini menjadi penting untuk diperhatikan baik bagi kalanga akademisi maupun bagi para praktisi hukum karena nilai ini merupakan titik awal atau atas dasar lahirnya konsep keadilan restoratif.

Pendekatan keadilan restoratif merupakan sebuah paradigma baru dalam merespons terjadinya tindak pidana. Dalam perspektif pendekatan keadilan restoratif tindak pidana dipahami sebagai suatu 
sengketa atau konflik yang merusak hubungan antar individu dan masyarakat (bukan sekedar sebagai pelanggaran hukum dimana sebagai konsekuensinya pelakunya akan berhadapan dengan negara. Dengan kata lain korban atas terjadinya tindak pidana bukanlah negara mealainkan individu. Oleh karenanya kejahatan menciptakan kewajiban untuk memebenahi rusaknya hubungan akibat terjadinya suatu tindak pidana.

Menurut Van Ness sebagaimana dikutip oleh Rufinus Hotmaulana Hutauruk mempostulatkan beberapa model pendekatan sebagai pilihan alternatif yang dapat menggambarkan tempat dan kedudukan pendekatan keadilan restoratif dalam sistem hukum pidana yaitu sebagai berikut :

a. Unified System. Dalam masyarakat yang semakin sadar akan pentingya kesetaraan dalam hukum. Christie menyatakan bahwa negara telah mencuri konflik dari para pihak menjadi suatu pilihan yang dapat memberi pandangan untuk memvisikan pendekatan restoratif menggantikan peradilan pidana. untuk mengembalikan konflik itu ke pemiliknya yang berhak memerlukan suatu pendekatan yang benar-benar berbeda dalam mengelola pemberian proses-proses keadilan yang memungkinkan korban dan pelanggar dapat menentukan sendiri hasil penyelesaian konfliknya tersebut dan negara tidak memiliki hak mutlak atas konflik dimaksud, sehingga berdasar pandangan ini proses-proses penyelesaian tindak pidana melalui pendekatan restoratif seharusnya dapat menggantikan semua proses dalam sistem peradilan pidana pada umumnya.

b. Dual Track System. Model Dual Track System ini dapat dibuat menjadi suatu pendamping alternatif bersama sistem peradilan pidana yang ada. Dalam suatu model jalur ganda, proses restoratif dan proses tradisional akan berdampingan secara bersama-sama dimana para pihak dapat menentukan jalannya proses dari suatu kasus tertentu. Jika kesepakatan untuk memasuki proses restoratif tidak dapat dicapai (dengan konsensus semua pihak yang berkepentingan) maka sistem pengadilan peradilan pidana akan tetap tersedia. Jadi dalam hal ini pendekatan restoratif ditempatkan menduduki posisi primer sedangkan lembaga-lembaga formal adalah berperan sebagai suatu unsur pendukung.

c. Safeguard System. Model ini adalah suatu model yang dirancang untuk menangani tindak pidana melalui pendekatan restoratif dimana program-program restoratif akan menjadi sarana utama untuk menangani permasalahanpermasalahan tindak pidana. Dengan demikian hal ini berarti bahwa akan terjadi suatu peralihan besar dari sistem peradilan pidana pada umumnya yang akan mengalami reduksi ke sistem 
keadilan restoratf. Namun untuk kasuskasus tertentu akan tetap ditangani oleh sistem peradilan pidana kontemporer (kasus-kasus yang dianggap tidak sesuai untuk ditangani oleh suatu proses atau program restoratif).

d. Hybrid System. Dalam model ini proses penentuan atau penetapan seseorang bersalah diproses dalam sistem peradilan pidana pada umumnya dan kemudian dalam proses penentuan sanksi maka konsep pendekatan restoratif dapat dipergunakan untuk menentukan jenis sanksinya. Dalam system hybrida, baik respon pendekatan restoratif maupun respon peradilan pidana kontemporer dipandang sebagai bagian-bagian normatif dari sistem peradilan.

Praktek-praktek restoratif sebenarnya telah ada dalam kultur atau budaya Indonesia sebagaimana telah dilakukan di Sumatera Barat, sekalipun hal itu dilakukan oleh kalangan elit tertentu dari masyarakat. Dari pendekatan restoratif tersebut terdapat pandangan-pandangan umum tentang restoratif tersebut antara lain :

a. Tujuan keadian harus dimaknai sebagai pemulihan keadaan dan penggantian kerugian yang diderita korban.

b. Tujuan pemulihan dan ganti rugi adalah bagian dari proses perbaikan menyeluruh terhadap seluruh hubungan yang telah rusak termasuk untuk mencegah agar tindak pidana serupa tidak terulang kembali

c. Pengertian tindak pidana bukan hanya sekedar pelanggaran hukum terhadap negara, tetapi juga dimaknai sebagai perbuatan yang merusak hubungan antar individu dan individu, dan masyarakat serta individu.

d. Tindak pidana merupakan suatu perbuatan yang menimbulkan kerugian bagi korban yang harus dipulihkan.

e. Beban pembuktian dan penyelesaian tindak pidana bukan semata-mata beban dari negara, tetapi merupakan beban individu dan masyarakat.

f. Penyelesaian tindak pidana harus diselesaikan secara adil dan seimbang, melalui suatu forum diskusi dan dialog yang bersifat membangun bagi para pihak yang terlibat di dalamnya khususnya korban dan pelaku yang telah menyatakan rasa penyesalannya atau masing-masing keluarganya.

g. Proses pemulihan bertujuan untuk menyelesaikan konflik dan mencegah tindak pidana yang dapat dilakukan melalui serangkaian pilihan pertemuan antara keluarga atau masyarakat dan wakil pemerintah yang disesuaikan dengan kompleksitas masalah serta proses penyelesaian praktis lainnya. Pertemuan tersebut diperlukan untuk dapat mengambil keputusan bersama dan memastikan bahwa proses tersebut 
berjalan dengan aman, saling menghormati, dan dapat membimbing para pihak menghadapi hal-hal yang kritis. Pertemuan tersebut juga dimaksud untuk mencari pemecahan bagaimana menghadapi kejadian setelah timbulnya tindak pidana termasuk untuk memastikan kesejahteraan atau kepuasan materil dari si korban, penegasan kembali bahwa mereka tidak akan dipersalahkan, adanya perhatian kepada kebutuhan emosional korban, pemecahan terhadap setiap konflik antara korban dengan pelaku (baik karena kejahatan itu sendiri maupun yang sudah ada sebelumnya), pemecahan pertentangan yang terjadi diantara para anggota keluarga atau dengan masyarakat, memecahkan kesulitan-kesulitan antara pelaku dengan keluarganya serta temanteman lainnya sebagai akibat dari kejahatan tersebut, misalnya malu untuk mengenal pelaku, serta memberi kesempatan kepada pelaku untuk membebaskan rasa bersalah melalui permintaan maat dan penggantian kerugian.

h. Proses pemulihan juga meliputi tindakan mengatasi alasan-alasan /penyebab kejahatan yang bersangkutan, membuat rencana rehabilitasi, perjanjian antara anggota keluarga dengan masyarakat yang hadir berdasarkan suatu sistem dukungan bagi pelaku kejahatan, untuk memastikan bahwa ia mampu menaati rencana tersebut.

i. Peranan pemerintah adalah memelihara ketertiban umum, sedangkan peranan masyarakat adalah menciptakan dan memelihara perdamaian.

$$
\text { Penyelesaian perkara dengan }
$$
pemidanaan seringkali tidak memuaskan semua pihak dan tidak menimbulkan dampak positif baik bagi pelaku, korban dan masyarakat. Oleh karena itu perlu adanya pemikiran dan terobosan di bidang hukum tepatnya dalam metode penyelesaian perkara pidana melalui jalur non litigasi dengan prinsip-prinsip atau nilai-nilai keadilan restoratif yakni dengan menerapkan model ADR (Alternative Dispute Resolution) atau ada pula yang menyebutkan dengan istilah Apropriate Dispute Resolution.

Pemidanaan dan penjara bukanlah satusatunya solusi terbaik dalam menyelesaikan kejahatan atau tindak pidana pada khususnya kejahatan atau tindak pidana dengna kerusakan atau kerugian yang ditimbulkannya masih bisa direstorasi, sehingga kondisi yang telah rusak atau pihak yang dirugikan dapat dikembalikan ke keadaan semula. Restorasi tersebut memungkinkan adanya penghilangan stigma buruk dari masyarakat terhadap individu pelaku. Paradigma penghukuman tersebut dikenal sebagai restorative justice, dimana pelaku diwajibkan memperbaiki kerugian yang telah ditimbulkannya kepada korban, 
masyarakat dan pihak lain yang merasa dirugikan.

Penyelesaian perkara dengan prinsip keadilan restoratif salah satunya diimplementasikan dalam bentuk mediasi penal atau dalam beberapa istilah disebut juga dengan mediation in criminal cases, atau mediation in penalmatters. Untuk menggambarkan hal ini terdapat beberapa istilah yang digunakan tergantung dari bahasa yang digunakan.

Penyelesaian perkara pidana dengan prinsip keadilan restoratif salah satunya diimplementasikan dalam bentuk mediasi penal dinilai dan dirasakan sangat signifikan dalam proses penegakan hukum meskipun saat itu dapat dikatakan masih menyimpang dari prosedur sistem hukum. Oleh karenanya penyelesaian perkara pidana prinsip keadilan restoratif yakni dalam bentuk mediasi penal sudah selayaknya dimasukkan atau diatur secara tegas dalam sistem hukum yang berlaku. Di samping itu perlu untuk disadari bahwa penyelesaian perkara pidana dengan prinsip keadilan restoratif yakni dalam bentuk mediasi penal tidak dapat dilepaskan dari cita hukum dan asas-asas hukum yang didasarkan pada landasan filsafat hukum yaitu keadilan dan asas hukum dalam proses penyelesaian perkara yang mengacu pada sumber hukum tertulis dan sumber hukum tidak tertulis. Oleh karena itu penerapan konsep penyelesaian perkara pidana dengan jalur damai atau dikenal dengan istilah mediasi penal harus diterapkan dana dilaksanakan dengan mengacu pada nilainilai keadilan, nilai kepastian hukum, nilai kemanfaatan dengan tetap mempertimbangkan landasan filosofis, yuridis, dan sosiologis.

Meskipun demikian penerapan konsep penyelesaian perkara pidana dengan pendekatan keadilan restoratif yang diimplementasikan dengan penyelesaian perkara dengan jalur damai atau dikenal dengan istilah mediasi penal pada kenyataannya belum dapat dilaksanakan secara terpadu dan menyeluruh. Hal ini dikarenakan tidak sedikit aparat penegak hukum yang belum menyadari pentingnya penyelesaian perkara dengan jalur damai atau mediasi penal dan belum memahami konsep dan pengimplementasian penyelesaian perkara pidana dengan pendekatan keadilan restoratif oleh karena kedua konsep tersebut (konsep keadilan restoratif dan konsep mediasi penal) relatif baru dalam penegakan hukum pidana.

Dalam konsep penyelesaian perkara pidana dengan pendekatan keadilan restoratif yang diimplementasikan dengan penyelesaian perkara melalui jalur damai atau dikenal dengan istilah mediasi penal dinilai memiliki beberapa kelebihan. Kelebihan-kelebihan tersebut misalnya dapat menghindarkan seseorang masuk dalam lembaga pemasyarakatan, menghindari stigmatisasi terpidana, menghemat biaya 
negara, memulihkan kerugian korban dan masyarakat, menjaga hubungan kemasyarakatan, mencapai tujuan pemidanaan (efek jera dan pencegahan) dan lain sebagainya.

Penerapan penyelesaian perkara pidana dengan keadilan restoratif antara korban dan pelaku dilakukan dengan cara-cara yaitu :

a. Menyelenggarakan pertemuan yang mengundang korban, pelaku dan keluarga yang mendukung mereka

b. Memberikan kesempatan kepada semua pihak untuk menceritakan bagaimana kejahatan yang telah terjadi dan mengusulkan solusi atau rencana aksi

c. Setelah pelaku dan keluarganya mendengarkan pendapat pihak lain, beri mereka kesempatan untuk mengusulkan solusi akhir yang dapat disetujui oleh semua pihak yang hadir.

d. Awasi pelaksanaan dari proposal tersebut terutama yang berkaitan dengan kompensasi untuk korban.

Konsep atau pendekatan keadilan restoratif harus dilaksanakan secara terintegrasi antara kepolisian, kejaksaan, hakim, lembaga pemasyarakatan, komisi yudisial dan advokat. Di samping itu bahwa pelaksanaan atau implementasi konsep atau pendekatan keadilan restoratif harus diaplikasikan dalam struktural, subtansial dan kultural sistem peradilan pidana terpadu Indonesia. Hal in menjadi penting mengingat apabila salah satu dari komponen tersebut tidak menerapkan konsep atau pendekatan keadilan restoratif maka putusan yang restoratif tidak mungkin dapat terlaksana. Misalnya kepolisian, dan kejaksaan telah menganut konsep keadilan restoratif namun hakim masih menganut pola pikir yang legistis, dalam kasus seperti ini hakim akan menjatuhkan putusan yang sangat normatif sehingga lembaga pemasyarakataan tidak bisa menerapkan konsep keadilan restoratif. Oleh karenanya pendekatan atau konsep keadilan restoratif harus dilaksanakan secara terintegrasi antara komponen yang satu dengan komponen yang lainnya. Sebaliknya apabila satu komponen tidak menjalankan pendekatan atau konsep keadilan restoratif maka pendekatan atau konsep keadilan restoratif itu sendiri tidak akan terealisasi dengan baik.

\section{Kesimpulan}

Konsep restorative justice belum diatur secara jelas dalam sistem peradilan pidana Indonesia sehingga menempatkan penegak hukum dalam posisi yang sulit dan dilematis mengingat penyelesaian perkara dalam perkara pidana saat ini sangat formalistik legalistik. Pendekatan atau konsep keadilan restoratif pada dasarnya telah ada dan telah lama dipraktekkan dalam kehidupan bermasyarakat Indonesia. Hal ini karena nilai-nilai perdamaian yang terkandung dalam pendekatan atau konsep keadilan restoratif sesuai dengan nilai-nilai yang terdapat dalam hukum adat dan hukum islam 
serta sesuai pula dengan nilai-nilai pancasila. Hukum Pidana Islam dan hukum adat (khususnya hukum pidana adat) sebagai living law di Indonesia sangat menganjurkan penyelesaian sengketa dengan cara perdamaian. Dengan demikian bagi kedua sistem hukum ini, segala sengketa bisa didamaikan apabila ada kesepakatan antara pelaku dan korban. Semangat perdamaian kedua sistem hukum yang telah lama ada di Indonesia ini tentunya sama dengan semangat atau nilai-nilai yang terdapat dalam konsep keadilan restoratif. Negara Indonesia adalah negara hukum. Penegakan hukum pidana di Indonesia harus dilaksanakan secara terintegrasi yakni dalam koridor sistem peradilan pidana yang terpadu sebagaimana diatur secara tegas dalam Kitab Undang-Undang Hukum Acara Pidana. Meskipun demikian perlu diketahui bahwa dalam sistem hukum di Indonesia saat ini tidak mengakui adanya mediasi dalam sistem peradilan pidana. akan tetapi dalam prakteknya di lapangan banyak perkara pidana diselesaikan melalui mekanisme dengan pendekatan restoratif yang merupakan inisiatif dari aparat penegak hukum sebagai bagian dari penyelesaian perkara, sebagai pengimplementasian hukum pidana adat maupun hukum pidana Islam. Dalam konsep keadilan restoratif ini memberikan perhatian yang sama terhadap korban dan pelaku. Di samping itu otoritas untuk menentukan rasa keadilan masyarakat berada di tangan para pihak, bukan pada penguasa (negara). Semangat penyelesaian perkara dengan pidana dengan restoratif yang berdasarkan perdamaian antara korban atau keluarga dengan melibatkan komunitas dan aparat penegak hukum untuk membicarakan masalah hukumnya dengan mengedepankan prinsip-prinsip win-win solution yang menjadi harapan masyarakat Indonesia sehingga penjara yang ada di Indonesia tidak penuh sesak seperti sekarang ini.

\section{Referensi}

Afhonul Afif, (2015), Pemaafan, Rekonsiliasi, \& Restorative Justice, Pustaka Pelajar, Yogyakarta.

Bambang Waluyo, (2015), Penegakan Hukum di Indonesia, Sinar Grafika, Jakarta

Burt Galaway and Joe Hudson, (2011), Criminal Justice, Restitution and Reconciliationn(criminal justice), Monsey, NY: Criminal Justice Press,

Eva Achjani Zulfa, (2012), Pergeseran Paradigma Pemidanaan, Lubuk Agung, BandungNatangsa Surbakti, 2015, Peradilan Restoratif Dalam Bingkai Empiri, Teori dan Kebijakan, Genta Publishing, Yogyakarta

Gordon Bazemore and Mara Schiff, (2010), Juvenile Justice Reform and Restorative Justice: Building Theory and Policy Form Practice, Willan Publishing, Oregon.

T.J. Gunawan, (2015), Konsep Pemidanaan Berbasis Nilai Kerugian Ekonomi, Genta Press, Yogyakarta 
Teguh Prasetyo dan Abdul Halim Barkatullah, (2012), Filsafat, Teori dan Imu Hukum:Pemikiran Menuju Masyarakat Yang Berkeadilan dan Bermartabat, Raja Grafindo Persada, Jakarta.

Nur Rochaeti, (2016), Keadilan Restoratif Dalam Sistem Peradilan Pidana Anak di Indonesia, Makalah Pelatihan
Viktimologi Indonesia, 18-20 September 2016, Purwokerto, Jawa Tengah

Kuat Yudi Prayitno, Restorative Justice Untuk Peradilan di Indonesia (Perspektif Yuridis Filosofis dalam Penegakan Hukum in Concreto), dalam Jurnal Dinamika Hukum, Vol. 12, No 3 September 